\title{
EMBER-GÉP KOMMUNIKÁCIÓ ÉS KRÍZISMENEDZSMENT. AUTÓIPARI BESZÁLLÍTÓI TAPASZTALATOK
}

\section{HUMAN-MACHINE COMMUNICATION AND CRISIS MANAGEMENT. AN AUTOMOTIVE INDUSTRY CASE STUDY}

\author{
Bakos Levente \\ Sapientia EMTE, Marosvásárhelyi Kar, Gépészmérnöki Tanszék, Marosvásárhely, Románia \\ bakos@ms.sapientia.ro
}

\begin{abstract}
The article presents some results of a larger study of crisis management in the automotive supply industry. This paper studies human - machine communication during organizational crises, an issue that can make the difference between success and failure. The topic is even more challenging in the highly standardized and regulated automotive industry. Using some methodologies taken from social sciences, we analyse the manner in which employees in the automotive supply industry handle unforeseen events. In spite of the increased number of standards and regulations, employees display ambiguous behaviour during unforeseen events, affecting trust in human-machine communication.
\end{abstract}

Keywords: human-machine communication, crisis management, risk management.

\section{Összefoglalás}

A tanulmány egy átfogóbb kutatás autóipari tapasztalatait mutatja be. A kríziskommunikáció hatékonyságának igen fontos paramétere a krízis során jelen levő ember-gép interakció minősége. Különösen érdekes kihívás ebben a kérdéskörben az igen magas szabályozottsággal rendelkező autóipar. Társadalomtudományok kutatási módszertanát alkalmazva a tanulmány azt taglalja, hogy miként viszonyulnak a váratlan eseményekhez a vizsgált autóipari beszállítók munkatársai. Az eredmények azt mutatják, hogy a magas szervezettség ellenére, az előre nem tervezett helyzetekben az alkalmazottak elbizonytalanodnak, az ember-gép kommunikációba vetett hit szélsőséges.

Kulcsszavak: ember-gép kommunikáció, krízismenedzsment, kockázatmenedzsment.

\section{Kockázat. Krízis. Kommunikáció}

A szervezeteken belüli kockázatmenedzsment igen fontos területté fejlődött. A dinamikusan változó körülmények odafigyelésre késztetik a piacok legerősebb szereplőit is. A piaci, technológiai, pénzügyi és egyéb kockázatcsaládok még a legtőkeerősebb vállalatokat is körültekintő, proaktív magatartásra serkentik. A soros egymásrautaltság arra kényszeríti a logisztikai láncok szereplőit, hogy kiemelt figyelmet fordítsanak a kockázatmenedzsmentre. Az iparban a legelterjedtebb minőségügyi szabványcsaládok (lásd ISO9000 [1],
ISO 14000 [2]) nagy teret szentelnek a kockázatok kezelésének, illetve a projektmenedzsment-módszertanok is gyakorlati és elméleti támpontot nyújtanak a kockázatok kezelésére [3]. A kifejezetten kockázatkezelésre kifejlesztett ISO 31000as szabvány [4] az alábbi kockázatelemzési eljárást javasolja (1. ábra). Ugyanakkor, túl a szabványok által javasolt ciklikus elemzéseken, illetve a számtalan szabályzaton, lehetetlen feltérképezni az összes kockázati tényezőt, s ha lehetne, akkor is műszakilag és gazdaságilag értelmetlen mindenre felkészülni. 


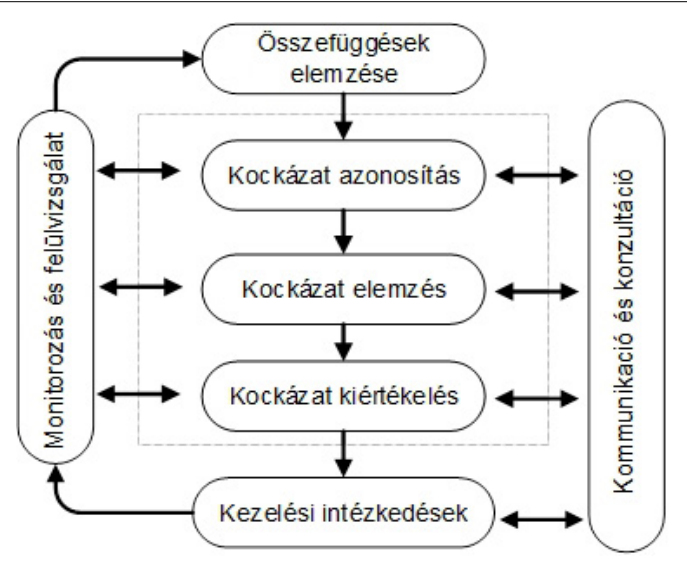

1. ábra. Kockázatmenedzsment az ISO 31000 szerint

A szervezetek mindig is szembesülni fognak olyan helyzetekkel, amelyekre nincsenek felkészülve, s amelyek, ha nem tudnak rájuk gyorsan reagálni, akár krízishez is vezethetnek.

Krízis fogalma alatt itt olyan váratlan eseményt értünk, amely hirtelen jelentkezik, a szervezet egészére kihat, és meghatározó következményekkel járhat a szervezet jövőjére vonatkozóan [5]. A mi megközelítésünkben a krízis kialakulásának három alapvető forgatókönyve lehetséges. Az első, valószínűleg leggyakoribb eset, amikor olyan esemény történik, amire korábban senki nem gondolt, emiatt a kockázatmenedzsment nem számolt vele. A második forgatókönyv szerint az ismert kockázati tényezők valósulnak meg, de a krízis oka vagy az ismert tényezők egyidejü jelentkezése, vagy ezek váratlan kombinációja. A harmadik esetben egyszerűen a vártnál lényegesen nagyobb intenzitással következett valamely nemkívánatos esemény. Elvileg minden más esetben a szervezet által kidolgozott kockázatkezelési algoritmusok életbelépésével a szervezet eredményesen kezeli a kialakult helyzetet. Ebben a megközelítésben a krízismenedzsment nem más, mint az a menedzsmentfolyamat, amely akkor kezdődik, amikor a kockázatmenedzsment által kidolgozott eljárások már nem alkalmazhatók.

A krízis következményei gyakran sokkal az adott incidens bekövetkezése után alakulnak ki. A mi megközelítésünkben a krízis kimenetele lehet pozitív is, ami azt jelenti, hogy a szervezet a krízis után kedvezőbb helyzetben találja magát, mint a krízishelyzet bekövetkezése előtt [6]. Különbséget kell tennünk a rövid távú, elsődleges hatás és a hosszú távú hatás között. A rövid távú hatás esetében a pillanatnyi - elsősorban anyagi -

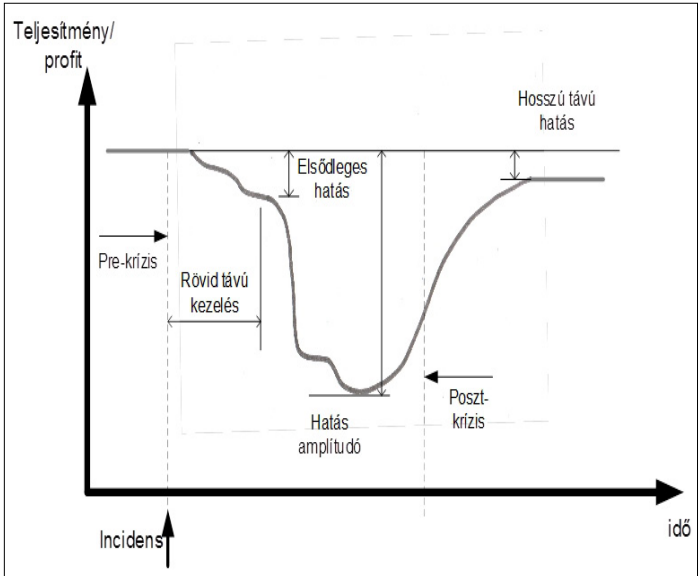

2. ábra. A krízis rövid és hosszú távú hatása

károk csökkentése a cél, míg hosszú távon inkább a hírnévmenedzsment kerül a figyelem középpontjába (2. ábra).

A krízismenedzsment során a rövid távú hatásokkal, illetve a közép- és hosszú távú következményekkel egyaránt számolni kell, emiatt csak a műszaki jellegű problémák megoldása közel sem elégséges. Előfordulhat, hogy a hibás kríziskommunikáció nagyobb károkat okoz, mint a krízis maga. Fontos a hatékony hibaelhárítás - hiszen itt is kommunikációs okok miatt rövid idő alatt hatványozódhat a kár -, ugyanakkor a felelősség elhallgatása, a hatóságokkal és más stake-holderekkel (pl. sajtó, ügyfelek, beszállítók) való kommunikáció elmulasztása sokkal többe kerül hosszú távon, mint a pillanatnyi anyagi kár [7]. Gondoljunk csak arra az autóipari példára, amikor egy hibás tervezésü felfüggesztés miatt egy tesztautó felborul a nyilvános bemutatón. Az igazi kár nem a behorpadt motorháztető, hanem az a többmilliós kár, ami akkor keletkezik, amikor utólag nyilvánosságra kerül, hogy nem vezetési hiba okozta a balesetet, $s$ a cég el akarta tussolni az eseményt.

Napjainkban a kialakult krízishelyzetek kezelésének kiemelten fontos kérdésköre a krízis-kommunikáció, s ezen belül az ember-gép közötti kommunikáció. Digitalizált világunkban, digitális eszközök nélkül nehezen kommunikálunk. Krízishelyzetben az ember-ember közötti kommunikáció is gyakran gépi segítséggel történik, emiatt itt is tulajdonképpen jelen van az ember-gép kapcsolat. Az ember-gép egyre komplexebb kapcsolatrendszere kockázatmenedzsmenti szempontból legalább akkora veszélyt jelent, mint amekkora lehetőséget a krízishelyzetek hatékony kezelésére [8]. 


\section{Ember-gép kapcsolat a krízishelyze- tekben}

A váratlan események során az ember-gép kapcsolatában két szélsőséges magatartásforma fordulhat elő. Egyrészt jelen lehet a túlzott bizalom a műszaki rendszerek által szolgáltatott adatokban és megoldásokban, másrészt az emberi erőforrás túlértékelése jelenti a másik végletet.

Ipari kontextusban a mérnökök lassan már minden elképzelhető folyamatot megpróbáltak és meg fognak próbálni automatizálni [9]. Kivételt képeznek azok a nem algoritmizálható helyzetek, amikor a megoldás szinte kizárólag az emberi erőforrásra hárul. Ilyen helyzetek a krízishelyzetek is, amikor a váratlan esemény kezelését az épp jelen levő humánerőforrástól várják [10]. Ez a „szuperhős-feltételezésnek” nevezett jelenség akkor következik be, amikor azt gondoljuk, hogy ha már semmi sem működik, akkor majd az ember közbelép, azonnal észleli a helyzetet, és tökéletes döntéseket hoz (3. ábra).

Több olyan terület van, ahol az előre nem látható események alatti ember-gép kapcsolat kiemelten szabályozott - lásd légiközlekedés, atomerőmüvek, haditechnika, sebészet -, míg más esetekben ez a felkészültség vélhetőleg lényegesen alacsonyabb [11]. Kutatásunk célja, hogy a humánerőforrás ilyen irányú felkészültségét vizsgálja. Azért választottuk az autóipari beszállítókat, mert tevékenységüket viszonylag magas szabályozottság jellemzi, szigorú nemzetközi szabályrendszer szerint müködnek. Úgy gondoltuk, hogy ha ebben az iparágban bármilyen felkészületlenséget, szabályozatlanságot észlelünk, akkor ez a jelenség valószínűleg más iparágakban nagyobb mértékben jelen van. A kutatás során megcélzott szélesebb vizsgálatból, jelen tanulmány korlátozott terjedelmét tekintve, itt most csak néhány leíró statisztikai adatot mutatunk be a következőkre vonatkozóan:

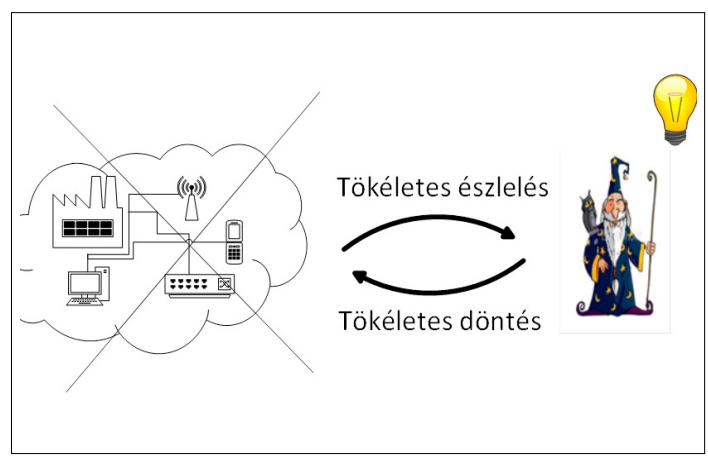

3. ábra. A szuperhős-effektus
-IT-eszközök használata szokatlan események során,

- IT-eszközök hatékonyságának értékelése krízishelyzetekben,

- hamis üzenetek kezelésének módja,

-attitűdvizsgálat, amennyiben nem müködik a kommunikációs interfész a számítástechnikai eszközökkel.

\section{Kutatásmódszertan. Eredmények}

A kutatás során tíz vállalat vezetőivel készítettünk szakértői interjút, illetve a kérdőíves felmérés során 151 munkatárs válaszait gyűjtöttük össze. A megkérdezettek elsősorban műszaki területen tevékenykedő, felsőfokú végzettséggel rendelkező középvezetők. A válaszadók között szerepelt néhány nem vezető beosztásban levő dolgozó is, ők munkakörükből adódóan kiemelt szereplői lehetnek egy krízishelyzetnek. Olyan területek képviselőit is megkérdeztük, mint például a tűzvédelem, munkavédelem vagy közkapcsolatok. Szakterületükből adódóan, a műszaki személyzethez hasonlóan, ezekről a munkatársakról is feltételezhető a kiemelt problémamegoldó készség és az átlagosnál jobb felkészültség a kiszámíthatatlan helyzetek kezelésére.

A 4. ábrán a válaszadók azon hajlandóságát mutatjuk be, hogy milyen mértékben tartanák be a szervezet szabályait egy krízishelyzet esetén. Az ábrából kitűnik, hogy a válaszadók 40\%-a elfogadja, hogy a rendkívüli helyzet megköveti a szabályzatoktól való eltérést. Ugyanakkor a határozott nemmel válaszolók aránya is meglehetősen magas, hiszen a kérdőívet kitöltők közel egynegyede (24\%) minden körülmények között ragaszkodni fog a szervezet szabályaihoz. Valószínűleg olyan körülmények között is, amikor ezek a szabályok a helyzet megoldását akadályozzák, illetve még akkor is, ha a válaszadó tisztában van azzal, hogy a szabályok megírásakor a pilla-

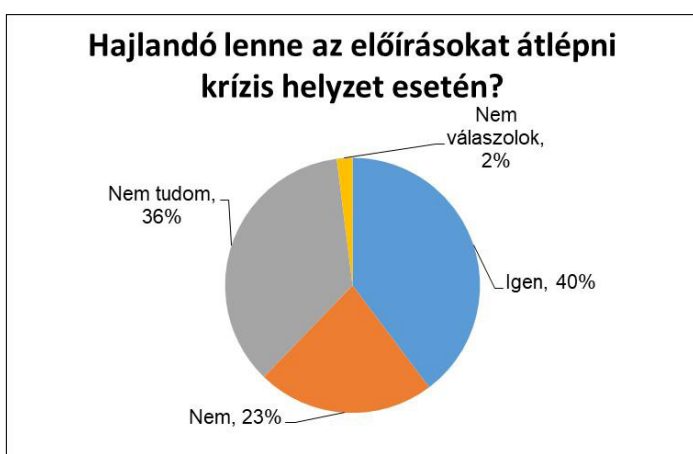

4. ábra. Szabályzatkövető szándék krízis esetén 
natnyi helyzetre nem gondoltak a szabályzatkészítők.

A fenti ábrán bemutatott szabályzatátlépő szándék, mivel csak a válaszadók 23\%-a tartana ki a szabályok mellett, nincs teljes összhangban az 5. ábrán bemutatott azon szándékkal, amely azt jelzi, hogy egy szervezeti rendellenesség esetében igenis a felettesükhöz fordulnak segítségért, betartva a szabályokat. Az 5. ábrán azt láthatjuk, hogy abban az esetben, amikor úgy értékeli a válaszadó, hogy a számítógépe hibás figyelmeztető üzenetet küld, a válaszadók fele a főnökéhez fordul a helyzet megoldása érdekében. Ez egy „helyes” magatartás, hiszen a rendkívüli helyzet ellenére a válaszadó szándéka a szervezeti hierarchia betartása, a fegyelmezett, szakszerü hozzáállás. Nyilvánvalóan a problémamegoldó hozzáállás azt feltételezné, hogy a rendszergazdához fordul a válaszadó. Ezt az opciót a válaszadók 30\%-a választotta, míg közel 20\%-uk a szervezet szempontjából előnytelen, teljesen passzív vagy a túlzottan kreatív megoldásokat részesítette előnyben. Érdekes, hogy a válaszadóknak csak 1\%-a lenne hajlandó a számítógép utasításait követni, holott az informatikai rendszert valószínűleg azért építették ki, hogy jelezze, ha valami nincs rendben.

Az előző kérdésre adott válaszokkal ellentétben azt láthatjuk, hogy abban az esetben, amikor a válaszadók a saját munkájuk eredményét látják veszélyben, illetve úgy érzik, hogy személyesen érintettek egy adott krízishelyzetben, akkor már teljesen más álláspontra helyezkednek. A 6 . ábrán látható, hogy ilyen esetben a válaszadók domináns többsége, 82\%-a ahhoz a személyhez fordul, akitől a probléma azonnali megoldását reméli. Ilyenkor a hierarchia, a szabályzatok betartása másodlagos, a helyzet kezelésének kulcsa a

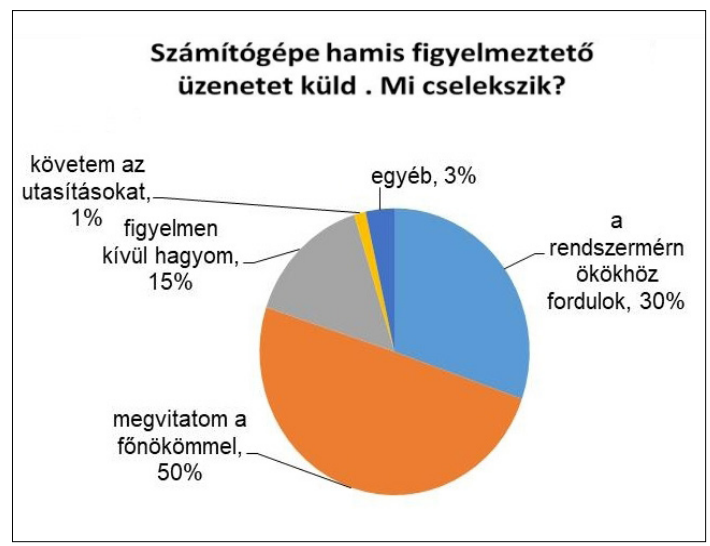

5. ábra. Hamis üzenet esetén történö reakció racionalitás, azaz a probléma tényleges megoldása. Szemben a korábbi válaszban adott 50\%-kal, itt csak a válaszadók 1\%-a fordulna a feletteséhez. A válaszadók 17\%-a nem tudja, mit fog cselekedni, vagy valamilyen kreatív megoldást fog keresni.

\section{Következtetések}

$\mathrm{Az}$ emberi erőforrás rendkívüli helyzetekben igen változatos szereplőjévé válhat az eseményeknek. Napjainkban immár a legegyszerübb munkatárs szintjén is jelen vannak a kommunikációt segítő digitális eszközök. Előfordulhat, hogy az ember főszereplőként kreatív és intuitív módon felnő a feladathoz és megoldja a helyzetet, ugyanakkor az is megeshet, hogy közömbös tanúja, tétlen áldozata az eseményeknek. A rendelkezésére álló digitális eszközök okozói és egyben megoldásai is lehetnek a kialakult krízishelyzeteknek. Az ember képes pillanatok alatt értékelni akár a legkomplexebb helyzeteket is, más esetekben pedig, meglepő módon, a rutinos helyzetekben is cselekvésképtelen.

Kutatásunk megerősítette azt a feltételezést, hogy túl a pillanatnyi ösztönszerü reakciókon, az ember képes a legbonyolultabb helyzetben a saját érdekeit is szem előtt tartani, és adott esetben félelem, gőg és érdek vezérelheti. Az eredmények azt mutatják, hogy a magas szervezettség ellenére, vagy pontosan emiatt, az előre nem tervezett helyzetekben az alkalmazottak vélhetőleg kaotikusan fognak reagálni. Amennyiben a kérdőív által megfogalmazott hipotetikus körülmények között is a válaszadók elbizonytalanodtak a lehetséges alternatívák tekintetében, akkor a valós helyzetekben kétségtelenül még inkább kiszámíthatatlan lesz a reakciójuk.

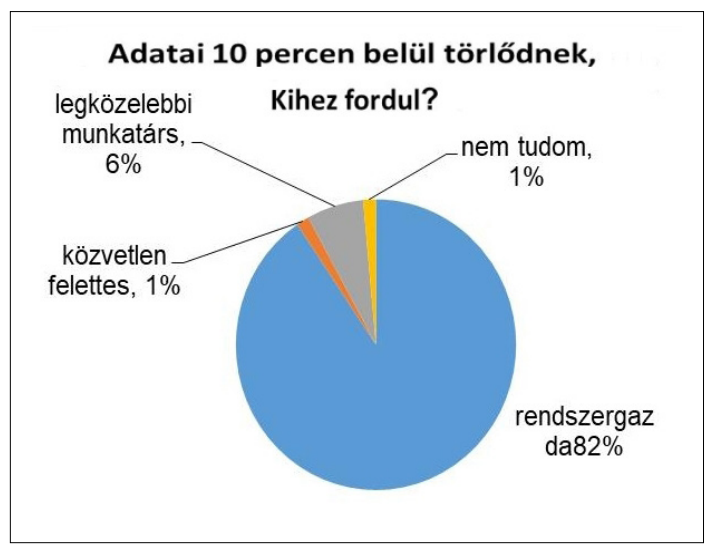

6. ábra. Reakció krízishelyzetben, személyes érintettség esetén 
Ezért tartjuk fontosnak a prevenciós tevékenység során tudatosítani a munkatársakkal, hogy azokban az esetekben, amikor a munkájuk során olyan helyzetbe kerülnek, amelyekre korábban nem volt példa, ez nem jelenti azt, hogy semmilyen felelősségük nincs ebben a helyzetben. A szabályok vagy a munkaköri leírás hiánya még nem mentesíti őket a felelősség alól. Például, túl a belső szabályzatokon, illetve más előre megírt normán, amennyiben elmulasztanak cselekedni egy olyan helyzetben, amikor ezt megtehették volna, s ezáltal kárt okoztak, nem mentesülnek a polgárjogi és büntetőjogi felelősségük alól.

A kutatások azt mutatják (lásd pl. [12]), hogy amennyiben a munkatársak felelősségük tudatában vannak, sokkal körültekintőbben viselkednek, és ezáltal a váratlan események megelőzésében és kezelésében önkéntelenül is aktívabb szerepet vállalnak fel. A vizsgált cégek vezetőivel folytatott interjúkból egyértelműen látszik a munkatársakba vetett hit, akár a szuperhős-effektus is, ugyanakkor a kérdésekre kapott válaszok arra utalnak, hogy közel sem elég felkészültek a középvezetők, munkatársak a szabályozatlan helyzetek kezelésére.

A vizsgált autóipari beszállító vállalatok esetében a humánerőforrás nem rendelkezik a kellő érettséggel a krízisszerü helyzetek kezelésére. A vizsgált beszállítók, bár nemzetközi szabványok mentén végzik tevékenységüket, ezekben a szervezetekben az ember-gép kapcsolat csak az előre megszabott működési keretek között egységes. A számítástechnikai eszközök használata, a beléjük vetett hit a krízisek esetén esetleges, nem egyértelmú.

Bár kétségtelenül a válaszadókban tudatosul, a kríziskommunikáció hatékonyságának igen fontos paramétere a krízis során jelen levő embergép interakció minősége, a kritikus szemlélet csak részlegesen jelent meg a válaszokban. Ugyanakkor jelen van a feltétlen bizalom és egyben a teljes bizalmatlanság is a gépi kommunikációra vonatkozóan. A vizsgált szervezetekben, azokra az esetekre, amikor előre nem látható események következnek be, kivéve a munkavédelmi és tüz- védelmi területeket (ezekre itt nem tértünk ki), a szervezet nem dolgozott ki általános érvényü eljárásrendet. Ezeknek a rendelkezéseknek a hiánya nehézkessé, időigényessé teszi a krízismenedzsmentet, és kizárólag a felsővezetésre bízza a megoldást.

\section{Szakirodalmi hivatkozások}

[1] MSZ EN ISO 9001:2015. Minőségirányítási rendszerek. Követelmények, 2015.

[2] EN ISO 14001:2015. Környezetközpontú irányítási rendszerek. Követelmények, 2015.

[3] ${ }^{* * *}$ A guide to the project management body of knowledge (PMBOK® guide). Fifth edition, Project Management Institute, 2013.

[4] MSZ ISO 31000:2018. Kockázatmenedzsment. Irányelvek, 2019.

[5] Barton L.: Crisis in Organisations: Managing and Communicating in the Heat of Chaos. SouthWestern College Publishing, Cincinatti, 1993. 2.

[6] Coombs W. T., Holladay S. J: The Handbook of Crisis Communication. Malden: MA, Wiley-Blackwell, 2010. 20.

[7] Patterson B.: Crises impact on reputation management. Public Relations Journal, 49/11. (1993) $47-48$.

[8] Valckenaers P., Van Brussel H.: Design for the unexpected. From holonic manufacturing systems towards a humane mechatronics society. Butterworth-Heinemann, Leuven, Belgium, 2015.

[9] Boy G. A.: Dealing with the Unexpected in our Complex Socio-Technical World. 12th IFAC Symposium on Analysis, Design, and Evaluation of Human-Machine Systems, August 11-15, 2013. Las Vegas, NV, USA, 2013. 402-409.

[10] Trentesaux D., Millot P.: A human-centred design to break the myth of the "Magic Human" in intelligent manufacturing systems. In: Service orientation in holonic and multi-agent manufacturing. (Szerk.: Borangiu T., Trentesaux D., Thomas A., McFarlane D.). 2016. 103-113.

[11] Pacaux-Lemoine M.-P. et al.: Designing intelligent manufacturing systems through Human-Machine Cooperation principles: A human-centered approach. Computers \& Industrial Engineering C, 111. (2017) 581-595.

[12] Tweedy J. T.: Introduction to Hazard Control Management. A Vital Organizational Function. CRC Press, London - New York, 2014. 